\title{
EFEKTIVITAS PELAYANAN KOPERASI KELOMPOK TANI MAYA SARI TERHADAP KESEJAHTERAAN MASYARAKAT
}

\author{
H.D. Suryatman ${ }^{1}$, Euis Puspitasari ${ }^{2}$ \\ IAIN Syekh Nurjati Cirebon ${ }^{1,2}$ \\ hd.suryatman@gmail.com
}

\begin{abstract}
ABSTARK
Para petani yang kurang modal dan kreativitas akan berdampak kerugian karena petani hanya mengandalkan hasil panen yang kurang maksimal sehingga kurangnya inovatif untuk mendapatkan income yang diinginkan. Meningkatkan perekonomian melalui anggota koperasi dimana di dalam anggota koperasi terdapat pelatihan-pelatihan untuk meningkatkan perekonomiannya, anggota koperasi sangat penting untuk dikembangkan di desa diantaranya desa kaliwedi yang memerlukan perkumpulan untuk meningkatkan pelayanan koperasi.Tujuan penelitian ini untuk mengetahui efektivitas pelayanan koperasi kelompok tani maya sari di desa Kaliwedi Kidul kecamatan Kaliwedi, untuk mengetahui kesejahteraan masyarakat di desa Kaliwedi Kidul kecamatan Kaliwedi, untuk mengetahui efektivitas pelayanan koperasi kelompok tani maya sari terhadap kesejahteraan masyarakat di desa Kaliwedi Kidul kecamatan Kaliwedi. Hasil Penelitian Berdasarkanhasil pengujian, diperoleh nilai $F_{\text {hitung }}$ sebesar 6,651> 1,664 dengan taraf signifikan $\alpha=0,05$ bahwa $F_{\text {hitung }}>F_{\text {tabel }}$ maka $H_{0}$ ditolak, artinya variabel efektivitas pelayanan koperasi kelompok tani maya sari berhubungan terhadap variabel kesejahteraan masyarakat. Hal ini diketahui dari probabilitasnya 0,00>0,05 (signifikan). Kesimpulan efektivitas pelayanan koperasi kelompok tani maya sari memiliki hubungan yang sangat kuat dengan kesejahteraan masyarakat.
\end{abstract}

Kata Kunci: Efektivitas, Pelayanan, Koperasi

\begin{abstract}
Farmers who lack capital and creativity will have an impact on losses because farmers only rely on less than optimal yields so that they are less innovative to get the desired income. Improving the economy through cooperative members where in cooperative members there are trainings to improve their economy, cooperative members are very important to be developed in villages, including Kaliwedi village, which requires associations to improve cooperative services.The purpose of this study was to determine the effectiveness of the virtual sari farmer group cooperative services in Kaliwedi Kidul village, Kaliwedi sub-district, to determine the welfare of the community in Kaliwedi Kidul village, Kaliwedi district, to determine the effectiveness of virtual sari farmer group cooperative services on community welfare in Kaliwedi Kidul village, Kaliwedi district.Research Results Based on the test results, it was found that the $F$ value was calculated $_{\text {at }} 6.651>1.664$ with a significant level of $\alpha=0.05$ that $F_{\text {count }}, F_{\text {table }}$ then $H_{0 \text { was }}$ rejected, meaning that the variable effectiveness of the virtual sari farmer group cooperative services was related to the variable of social welfare. This is known from the probability 0.00> 0.05 (significant). The conclusion is that the effectiveness of the virtual sari farmer group cooperative services has a very strong relationship with the welfare of the community.
\end{abstract}

Keywords : Effectiveness, Service, Cooperative

Jurnal Edueksos Vol IX, No. 2, Desember 2020

The journal of social and economics education 


\section{A. PENDAhUluan}

Kemiskinan hadir di tengah-tengah masyarakat, khususnya di negara berkembang. Kemiskinan tengah hadir di sekitar desa yang masyarakatnya kurang kreatif sehingga diperlukan kreativitas untuk mengurangi kemiskinan. Hal ini bukan saja kemiskinan dari desa tetapi kemiskinan hadir di sekeliling kita yang memang masyarakatnya belum mampu untuk meningkatkan kesejahteraan taraf hidup ekonominya.

Para petani yang kurang modal dan kreativitas akan berdampak kerugian karena petani hanya mengandalkan hasil panen yang kurang maksimal sehingga kurangnya inovatif untuk mendapatkan income yang diinginkan.Partisipasi masyarakat yang kurang jaringan sosialnya akan lambat berkermbang di bidang pertanian dan perkoperasian sehingga betapa pentinya modal sosial untuk meningkatkan perekonomian melalui anggota koperasi dimana di dalam anggota koperasi terdapat pelatihan-pelatihan untuk meningkatkan perekonomiannya, anggota koperasi sangat penting untuk dikembangkan di desa diantaranya desa kaliwedi yang memerlukan perkumpulan untuk meningkatkan pelayanan koperasi.Beberapa kelompok tani juga mempunyai kegiatan lain, seperti gotong royong, usaha simpan pinjam dan arisan kerja untuk kegiatan usaha tani (Hermanto dalam Muizu1, 2007).

Mata pencahariannya selain sektor formal diantaranya bertani di desa kaliwedi kidul. Anggota koperasi tidak hanya bapak petani tatapi perempuan mempunyai peranan yang penting sehingga dalam anggota koperasi terdiri dari laki-laki dan perempuan untuk bersama-sama memajukan koperasi demi kesejahteraan bersama akan tetapi ada saja masalah yang dihadapi oleh para anggota koperasi diantaranya Kurangnya tenaga yang profesional mengenai pengelolaan koperasi, keterbatasan modal, kurang peka terhadap lingkungan (pesaing), pemberdayaan masyarakat desa yang belum maksimal, Oleh karena itu peneliti tertarik untuk mengetahui bagaimana efektivitas pelayanan koperasi Kelompok Tani Maya Sari di Desa Kaliwedi Kidul kecamatan Kaliwedi, Bagaimana kesejahteraan masyarakat di desa Kaliwedi Kidul kecamatan Kaliwedi, Bagaimana efektivitas pelayanan koperasi Kelompok Tani Mayasari terhadap kesejahteraan masyarakat di Desa Kaliwedi Kidul kecamatan Kaliwedi. 
Tujuan Penelitian ini adalah untuk mengetahui efektivitas pelayanan koperasi kelompok tani maya sari di desa Kaliwedi Kidul kecamatan Kaliwedi, engetahui kesejahteraan masyarakat di desa Kaliwedi Kidul kecamatan Kaliwedidan mengetahui efektivitas pelayanan koperasi kelompok tani maya sari terhadap kesejahteraan masyarakat di desa Kaliwedi Kidul kecamatan Kaliwedi. Kemudian asumsi penelitian ini yaituefektivitas pelayanan sebagai barometer kesejahteraan masyarakat desa, pelayanan koperasi sangat penting untuk kesejahteraan masyarakat desa, efektivitas pelayanan koperasi sangat penting terhadap kesejahteraan masyarakat Desa Kaliwedi Kidul

\section{Efektivitas}

Efektivitas berasal dari kata dasar efektif, Efektivitas menekankan pada hasil yang dicapai, sedangkan efisiensi lebih melihat pada bagaiman cara mencapai hasil yang dicapai itu dengan membandingkan antara input dan outputnya. Semakin banyak rencana yang dapat dicapai, semakin efektif pula kegiatan tersebut sehingga kata efektivitas dapat juga diartikan sebagai tingkat keberhasilan yang dapat dicapai dari suatu cara atau usaha tertentu sesuai dengan tujuan yang hendak dicapai. Media pembelajaran bisa dikatakan efektif ketika memenuhi kriteria, diantaranya mampu memberikan pengaruh, perubahan atau dapat membawa hasil. Ketika kita merumuskan tujuan instruksional, maka efektivitas dapat dilihat dari seberapa jauh tujuan itu tercapai. Semakin banyak tujuan tercapai, maka semakin efektif pula media pembelajaran tersebut.

\section{Pelayanan (Manajemen Kualitas Pelayanan)}

Tjiptono dalam Wijaya (2016) pelayanan prima (service excellent) terdiri dari empat unsur pokok antara lain sebagai berikut Kecepatan, Ketepatan, Keramahan, Kenyamanan.Pelayanan koperasi pada dasarnya adalah sebuah proses yang melibatkan interaksi antara pihak yang melayani, dalam hal ini koperasi, dan pihak yang menerima pelayanan, yaitu anggota koperasi dan masyarakat umum. Dalam kaitannya dengan hal ini. Jadi pelayanan dalam koperasi adalah salah satu bentuk pelayanan yang sifatnya ke dalam maupun keluar. Karena pelayanan merupakan satu bentuk interaksi, maka keberhasilannya akan tergantung pada adanya kesesuaian antara yang memberi pelayanan dengan yang menerima 
pelayanan. Kesesuaian ini menurut studi human realations berupa kepuasan yang diperoleh kedua belah pihak. Dalam pelayanan tidak bisa memaksakan sesuatu yang tidak sesuai dengan kehendak para pelanggan. Sebaliknya, pelanggan juga tidak bisa meminta sesuatu kepada penyelenggara pelayanan untuk harus sesuai dengan yang mereka kehendaki. Jadi koperasi harus memberikan pelayanan sesuai dengan harapan dan keinginan para pelanggannya yaitu para sesama anggota koperasi maupun pelanggan masyarakat umum. Dalam rangka menjaga dan mewujudkan interaksi yang saling menguntungkan dalam penyelenggaraan pelayanan diperlukan serangkaian tindakan yang dalam teori manajemen dikenal dengan manajemen kualitas pelayanan, yang berfokus pada upaya perbaikan terus menerus untuk memenuhi kepuasan pelanggan. Manajemen kualitas berorientasi pada proses yang mengintegrasikan semua sumberpelanggan di lingkungan organisasi.

\section{Koperasi}

Koperasi ialah suatu badan hukum yang berlandaskan atas asas kekeluargaan yang semua anggota terdiri dari perorangan atau badan hukum dengan tujuan mensejahterakan anggotanya. Koperasi dapat diartikan badan usaha yang mempunyai anggota yang setiap anggota memiliki tugas dan tanggung jawab masing masing dimana pada anggota sehingga mempunyai hak suara yang sama pada setiap keputusan yang akan diambil selain itu menurut Putri Ayu, dkk kemajuan suatu koperasi tergantungpada keaktifan/partisipasi anggota terhadapkoperasinya. Koperasi unit desa merupakan koperasi diwilayah pedesaan yang bergerak dalam penyedian kebutuhan masyarakat yang berkaitan dengan kegiatan pertanian. Koperasi unit desa dapat juga dikatakan sebagai wadah organisasi ekonomi yang berwatak sosial dan merupakan wadah bagi pengembangan berbagai kegiatan ekonomi masyarakat pedesaan yang diselenggarakan oleh masyarakat dan untuk masyarakat itu sendiri. Koperasi unit desa dapat juga disebut sebagai koperasi serba usaha karena berusaha memenuhi berbagai bidang seperti simpan pinjam, kosumsi, produksi, pemasaran dan jasa. Koperasi unit desa diharapkan dapat menjadi tiang perekonomian serta mampu berperan aktif untuk memperluas perekonomian skala kecil dan usaha keluarga di 
desa, dengan cara membantu menyalurkan sarana produksi dan memasarkan hasil pertanian. Selain itu koperasi unit desa juga diharapkan dapat memberikan bimbingan teknis kepada petani yang masih menggunakan teknologi tradisonal yaitu dengan mengadakan penyuluhan dan kursus bagi petani. Bimbingan dan penyuluhan bagi para petani sangat dibutuhkan karena untuk meningkatkan produksi hasil pertananian. Dengan adanya hal tersebut diharapkan tujuan akhirnya mampu meningkatkan kesejahteraan bagi petani yang ada wilayah pedesaan.

\section{Kesejahteraan Masyarakat}

Masyarakat mengharapkan kesejahteraan yang dinamis sehingga mampu untuk menyekolahkan anak, kesehatan terjamin, sandang pangan tercukupi perekonomian semakin meningkat, kesejahteraan merupakan tujuan utama masyarakat. Peran pemerintah sangat penting untuk membantu mensejahterakan masyarakatnya sehingga penerapan kebijakan sesuai dengan rancangan pemerintah, peran pemerintah dan masyarakat sangat penting untuk kesejahteraan masyarakat sehingga satu sama lain saling mendukung untuk peningkatan kesejahteraan. Otonomi daerah merupakan pengembangan dari otoritas pemerintah untuk mengembangkan daerahnya masing-masing yang diberi wewenang untuk mengelola daerah.

\section{Kajian Penelitian Relevan}

Persamaan pada penelitian, penelitian yang dilakukan oleh Anggeliane Lintang (2018) yaitu penelitiannya menggunakan kuantitatif dan membahas mengenai kesejahteraan masyarakat.Perbedaan pada penelitian adanya koperasi wanita tani dapat meningkatkan kesehateraan masyarakat desa kaliwedi kidul

\section{B. METODE PENELITIAN}

Penelitian dilakukan dengan metode deskriptif terhadap masyarakat desa Kaliwedi Kidul. Penelitian ini bertempat di desa Kaliwedi Kidul dengan populasi yang akan di ambil pada penelitian sejumlah 100 orang. Menurut Suharsimi Arikunto (1998:117) "Sampel yaitu sebagian atau wakil populasi yang diteliti”. Sedangkan menurut Sugiarto (2001:2) Sampel yaitu sebagian anggota dari 
populasi yang dipilah dengan menggunakan prosedur tertentu sehingga diharapkan dapat mewakili populasinya”. Pada penentu sampel sejumlah mahasiswa yang dilakukan melalui perhitungan dengan menggunakan rumus slovins (Riduwan 2004: 65 ). Dari hasil perhitungan, maka ukuran sampel minimal dalam penelitian ini adalah 80 orang. Dalam penelitian ini teknik penentuan sampel dilakukan melalui metode Stratified random sampling dengan menggunakan metode pengambilan sampel yang bertujuan agar dapat menggambarkan secara tepat sifat populasi yang heterogen. (Singarimbun, 1995:162).

Teknik dan pengumpulan data yang digunakan yaitu data yang diperoleh langsung dari responden melalui kuesioner (data primer) diantaranya Kuesioner, studi dokumentasi, dan studi literatur. Pengujian validitas instrument penggunaannya untuk pengukuran berapa besar suatu alat ukur dalam melakukan fungsinya untuk ketepatan dan kecermatan. Validitas pada penelitian ini menjelaskan sebagai suatu ukuran ketepatan dalam alat ukur penelitian tentang isi pada penelitian yang diukur. Pengujian validitas instrument yaitu untuk mendapatkan ukuran yang valid dari data yang diperolehdan data pengukuran yang diyakini. Pengujian validitas instrument adalah dengan menggunakan teknik Pearson product moment. Pengujian reliabilitas pada penelitian yang digunakan menggunakan teknik Alfa Cronbach.

Teknik analisis data pada penelitian ini menggunakan regresi yaitu proses memprediksikan secara sistematis mengenai apa yang paling mungkin terjadi dimasa yang akan datang sesuai informasi masa lalu dan sekarang yang dimiliki supaya kesalahan dapat diperkecil (Riduwan dan Sunarto,2009:96). Uji normalitas digunakan untuk mengetahui normal tidaknya suatu distribusi data. Uji normalitas dapat digunakan dengan uji Chi Square (uji kecocokan). Uji homogenitas dilakukan untuk mendapati sampel satu dengan lainnya memiliki persamaan atau tidak sehingga menguji tingkat homogenitas tersebut menggunakan statistik uji F. Dan rumus yang digunakan untuk mencari koefisien validitas secara keseluruhan adalah rumus Pearson Product Moment. 


\section{HASIL PENELITIAN DAN PEMBAHASAN}

\section{Efektivitas Pelayanan Koperasi Gabungan Kelompok Tani Mayasari}

Koperasi gabungan kelompok tani mayasari merupakan koperasi diwilayah Kaliwedi Kidul, Partisipasi anggota diukur dari kesediaan anggota itu untuk memikul kewajiban dan menjalankan hak keanggotaann secara bertanggungjawab jika sebagian besar anggota koperasi sudah menunaikan kewajiban dan melaksanakan hak secara bertanggungjawab maka partisipasi anggota koperasi yang bersangkutan sudah dikatakan baik. Pelayanan koperasi kelompok tani di desa kaliwedi kidul mempunyai sistem yang sistematis antara para anggota koperasi, pengurus koperasi dan anggota koperasi satu sama lain saling menghargai dan pengelolaan koperasi yang transfaran sehingga anggota koperasi mempunyai keuntuntungan untuk meningkatkan kesejahteraan.

\section{Kesejahteraan Masyarakat di Desa Kaliwedi Kidul kecamatan Kaliwedi}

Koperasi tidak saja mempunyai tujuan kebendaan (ekonomis), akan tetapi berusaha memajukan segi-segi sosial anggota dan kesejahteraan ekonomi pada koperasi gabungan kelompok tani mayasari. Betapa pentingnya pendidikan pada koperasi baik untuk tujuan memperoleh skill maupun untuk mencapai moral yang tinggi, dalam hal ini Suyatno dalamCyntia Putri Devanty,dkk(2005) menyampaikan bahwa kesejahteraan masyarakat dapat ditandai dengan berkurangnya tingkat kemiskinan, kesehatan menjadi lebih baik, dapat memperoleh tingkat pendidikan yang tinggi, dan peningkatan produktivitas masyarakat. Menurut Haryanto, Rudy (2016) dari beberapa hasil studi kasustentang koperasi memperlihatkan bahwa keberadaan koperasi tidak sajamenguntungkan pada anggota koperasi tetapi juga telah berperan dalampenyerapan tenaga kerja dan memberikan tingkat kesejahteraan yang lebih baikuntuk komunitas dimana koperasi tersebut berada.

Koperasi kelompok tani mayasari berdasarkan kesukarelaan, koperasi mengembangkan demokrasi, secara mendidik anggotanya ke arah percaya pada diri sendiri dan kesejahteraan anggota gabungan kelompok tani maya sari untuk mencapai tujuan tindakan yang dinamis diantaranya melakukan tindakan-tindakan yang bersifat menghemat atau menambah efisiensi, selanjutnya berhasilnya 
pelayanan koperasi sangat tergantung dari besar kecilnya tanggungjawab anggota yang dalam perkumpulan koperasi dikembangkan dengan mengadakan peraturan tanggungan anggota dalam koperasi dipergunakan ukuran dan yang sama untuk mencapai tujuan yang sama yaitu kesejahteraan.

Koefisien determinasi mempunyai arti bahwa besarnya kontribusi efektivitas pelayanan koperasi kelompok tani maya sari terhadap kesejahteraan masyarakat sebesar 7,9 \% maka 2,1\% dipengaruhi oleh faktor lain. Hasil penilitian menunjukkan dengan adanya Kelompok Tani Maya Sari dapat membantu kesejahteraan masyarakat kaliwedi. Kondisi kesejahteraan masyarakat desa kaliwedi sudah masuk ke dalam kategori sejahtera, ini dapat dilihat mulai dari pembangunan desanya, pembinaan masyarakat dalam bidang keagamaan, pertanian dan pendidikan social budaya yang sudah sangat memadai untuk kemajuan desa kaliwedi. Berbagai kegiatan yang sudah ada tentunya sangat menunjang kegiatan masyarakat untuk menuju masyarakat yang sejahtera.

\section{Efektivitas Pelayanan Koperasi Kelompok Tani Mayasari terhadap} Kesejahteraan Masyarakat di Desa Kaliwedi Kidul kecamatan Kaliwedi

Pelayanan koperasi gabungan kelompok tani mayasari memiliki standar pelayanan sebagai jaminan adanya kepastian bagi penerima pelayanan. Standar pelayanan merupakan ukuran yang dibakukan dalam penyelenggara pelayanan koperasi gabungan kelompok tani mayasari yang wajib ditaati oleh pemberi atau penerima pelayanan.

Berdasarkan hasil pengujian, diperoleh nilai $F_{\text {hitung }}$ sebesar 6,651> 1,664 dengan taraf signifikan $\alpha=0,05$. Dapat disimpulkan bahwa $F_{\text {hitung }>} F_{\text {tabel }}$ maka $H_{0}$ ditolak, artinya bahwa variabel efektivitas pelayanan koperasi kelompok tani maya sari berhubungan terhadap variabel kesejahteraan masyarakat. Hal ini diketahui dari probabilitasnya 0,00>0,05 (signifikan). Temuan ini menunjukan bahwa efektivitas pelayanan koperasi kelompok tani maya sari memiliki hubungan yang sangat kuat dengan kesejahteraan masyarakat.

Berdasarkan hasil SPSS diatas nilai pearson correlation antara Efektivitas Pelayanan Koperasi terhadap Kesejahteraan Masyarakat sebesar 0,280. Maka korelasi tersebut termasuk kategori korelasi positif yang cukup tinggi dengan 
begitu bahwa koefisien $\mathrm{X}$ pada persamaan regresi diatas menunjukan adanya korelasi antara efektivitas pelayanan koperasi dengan kesejahteraan masyarakat.

\section{KESIMPULAN}

Koperasi gabungan kelompok tani Mayasari merupakan koperasi diwilayah Kaliwedi Kidulpartisipasi anggota diukur dari kesediaan anggota itu untuk memikul kewajiban dan menjalankan hak keanggotaann secara bertanggungjawab jika sebagian besar anggota koperasi sudah menunaikan kewajiban dan melaksanakan hak secara bertanggungjawab maka partisipasi anggota koperasi yang bersangkutan sudah dikatakan baik. Pelayanan koperasi kelompok tani di desa kaliwedi Kidul mempunyi sistem yang sistematis antara para anggota koperasi, pengurus koperasi dan anggota koperasi satu sama lain saling menghargai dan pengelolaan koperasi yang transfaran sehingga anggota koperasi mempunyai keuntungan untuk meningkatkan kesejahteraan.

Berdasarkan hasil SPSS di atas nilai pearson correlation antara efektivitas pelayanan koperasi terhadap kesejahteraan masyarakat sebesar 0,280. Maka korelasi tersebut termasuk kategori korelasi positif yang cukup tinggi. Dengan begitu berarti bahwa koefisien $\mathrm{X}$ pada persamaan regresi di atas menunjukan adanya korelasi antara efektivitas pelayanan koperasi dengan kesejahteraan masyarakat.

Berdasarkan hasil pengujian, diperoleh nilai $\mathrm{F}$ hitung sebesar 6,651>1,664 dengan taraf signifikan $\alpha=0,05$. Dapat disimpulkan bahwa $F$ hitung $>$ Ftabel maka H0 ditolak, artinya bahwa variabel efektivitas pelayanan koperasi kelompok tani maya sari berhubungan terhadap variabel kesejahteraan masyarakat. Hal ini diketahui dari probabilitasnya 0,00>0,05 (signifikan). Temuan ini menunjukan bahwa efektivitas pelayanan koperasi kelompok tani maya sari memiliki hubungan yang sangat kuat dengan kesejahteraan masyarakat.

\section{REFERENSI}

Abrar Basyaib (2017) Koperasi sebagai Wadah Kesejahteraan bagi anggotanya

(Online) Tersedia di https://prolegal.id/2017/02/08/koperasi-sebagai-wadahkesejahteraan-bagi-anggotanya/ 
Agustitin Setyobudi (2018)Manajemen Kualitas Pelayanan dan Efektivitas Pembinaan (online) Tersedia dihttp://majalahukm.com/manajemen-kualitaspelayanan-dan-efektivitas-pembinaan/

Arikunto, Suharsimi. (1998). Prosedur Penelitian Suatu Pendekatan Praktek. Jakarta: PT. Rineka Cipta

Devanty, Cyntia Putri, dkk. (2017). Peran Koperasi Wanita dalam Upaya Pemberdayaan Perempuan Pada Koperasi Wanita di Kecamatan Blahbatuh Kabupaten gianyar. E-Jurnal Ekonomi Pembangunan Universitas Udayana, 6(4), 472-498.

Haryanto, Rudy. Peningkatkan Ekonomi Kerakyatan Melalui Penguatan Managerial Koperasi Wanita Di Kecamatan Pademawu Kabupaten Pamekasan. Jurnal, vol. 13 , No. 2

Hasyim (2016) Dana Desa dan Masa Depan Pertanian (Online) Tersedia di http://aceh.tribunnews.com/2016/05/21/dana-desa-dan-masa-depan-pertanian

Muizul, W. O. Z. (2007). Rancangan Kelembagaan Tani dlam Implementasi Prima Tani di Sumatera Selatan. Jurnal Analisis Kebijakan Pertanian, 5(2), 110-125.

Imam Y. Handoko (2018) Peranan dan Manfaat Koperasi Unit Desa (Online) Tersedia dihttps://mobilanlisterikindonesia.blogspot.com/2018/06/peranan-danmanfaat-koperasi-unit-desa.html.

Lintang Anggeliane (2018) peranan Pemerintah Desa dalam Menunjang Peningkatan Kesejahteraan Masyarakat Desa. Jurnal

Pratiwi Raharjo, putri ayu, dkk (2017). Peran Koperasi Terhadap Pengembangan Partisipasi Anggota (Studi Kasus di KUD Tani Makmur, Kecamatan Kasihan, Kabupaten Bantul, Provinsi Daerah Istimewa Yogyakarta). Jurnal Masepi, vol.2, No.1

Riduwan. (2004). Metode \& Teknik Menyusun Tesis. Bandung: CV Alfabeta

Ridwan dan Sunarto. (2009). Pengantar Statistika. Bandung: Alfabeta

Singarimbun, Masri. (1995). Metode Penelitian Survey. Jakarta: LP3ES

Sugiarto. (2001). Teknik Sampling. Jakarta: Gramedia Pustaka Utama

Wijaya, Apriyanda Kusuma. Adelina Hasyim. Yunisca Nurmalisa. (2016). Hubungan Pemahaman tentang Kewajiban Peserta BPJS Kesehatan dengan Pemanfaatan Pelayanan Kesehatan, Jurnal kultur demokrasi (4) 1, FKIP Unila. http://jurnal.fkip.unila.ac.id/index.php/JKD/article/view/10604 
Wordpress (2017)Pengertian Pelayanan Prima Dan Contohnya Beserta Tujuannya. http://www.pengertianku.net/2017/03/pengertian-pelayanan-prima-dancontohnya-beserta-tujuannya.html

Zusnita Muizu, Wa Ode, dkk. (2019). Peranan Kelompok Tani (KWT) Tali Wargi dalam Pemberdayaan Masyarakat di Desa Citali, Kabupaten Sumedang. Jurnal Kewirausahaan, 1(1), 151-164 